\title{
Potensi Keramik Bone China sebagai Aksesoris Fashion Era Digital
}

\author{
Lusiana \\ Program Studi Magister Desain-Institut Teknologi Bandung \\ e-mail: zielusi.ilalang@gmail.com
}

\begin{abstract}
Abstrak. Keramik Bone China memiliki sifat tembus bayang. Abu tulang memberikan karakter unik pada keramik Bone China, menjadikannya berwarna putih, tembus bayang dan bobot yang ringan. Hingga saat ini pemanfaatan keramik Bone China masih berfokus pada karakter bobotnya yang lebih ringan dibandingkan material keramik lainnya. Sifat tembus bayangnya baru dimanfaatkan sebatas armature lampu dan perangkat hotel.

Penelitian ini merupakan studi deskriptif kualitatif dengan pendekatan analisa teori keramik, aksesoris fashion, teori perilaku konsumen Solomon \& Rabolt, dan beberapa data fenomena sebagai data tambahan untuk mengkaji peluang pemanfaat material keramik tembus bayang di dunia fashion era digital saat ini. Hasil yang diperoleh adalah keramik tembus bayang memiliki peluang besar untuk dimanfaatkan sebagai material produk aksesoris fashion dengan perpaduan konsep digital untuk kalangan menengah yang hidup di era perkembangan teknologi digital saat ini.
\end{abstract}

Kata Kunci : aksesoris, Bone China, digital, fashion, keramik

\begin{abstract}
Translucent is a physical properties of Bone China. Bone ash materials gives Bone China Ceramics their unique properties, milky white color, translucent and light weight impression. So far, the use of Bone China ceramics have been focused on the character of a lighter weight impression than other ceramic materials. Transparency properties is limited used as lamp armature and hotel ware.

This research is a qualitative descriptive study with theoretical analysis approach of ceramics, fashion accessories, consumer behavior theory by Solomon \& Rabolt, and some data of phenomena as additional data to assess the chances of utilization a translucent ceramic material for fashion in the digital era.

The results obtained are translucent ceramics has a great chance to be used as fashion accessories product with a mix of digital concept for middle class whose living in the digital era development.
\end{abstract}

Keywords: accessories, Bone China, ceramic, digital, fashion 


\section{Pendahuluan}

Globalisasi sebagai gerakan menuju terciptanya pasar atau kebijakan yang melintasi batas nasional tentu mempengaruhi tatanan masyarakat yang kian bergerak mendunia dan tidak lagi mengenal batas wilayah. Globalisasi yang dipahami saat ini adalah sebagai suatu konsep revolusi kegiatan ekonomi, teknologi serta komunikasi yang menawarkan berbagai peluang dan tantangan baru bagi umat manusia. Bagi setiap negara efek globalisasi bagaikan dua sisi mata uang, hal Ini pun terjadi di Indonesia dengan segala efek positif dan negatifnya.

Adanya globalisasi yang semakin pesat, saat ini Indonesia menjadi pemain penting dalam dunia fashion dan pengguna teknologi smartphone. Hal tersebut dapat dilihat dari terbentuknya Indonesia Islamic Fashion Consortium (IIFC) yang didukung oleh Kementerian Koordinator Perekonomian, Departemen Kebudayaan dan Pariwisata 2010 lalu. Departemen Perindustrian dan Departemen Perdagangan mencanangkan kampanye "Menuju Indonesia Sebagai Kiblat Fashion Muslim Dunia pada tahun 2020".

Selain itu, saat ini Indonesia menduduki posisi 5 besar pengguna aktif smartphone dan internet, data tersebut dilansir oleh analis kawakan Horace $\mathrm{H}$. Dediu melalui laman internet, asymco.com. Hal ini menunjukkan bahwa masyarakat Indonesia semakin terbiasa dengan penggunaan perangkat digital dan akses informasi tanpa batas dengan cepat dan realtime.

Dengan demikian masyarakat Indonesia mengalami kemajuan baik penghasilan maupun kesejahteraan, hal ini seiring dengan pendapat Kotler (2006) bahwa kemajuan tersebut akan memunculkan prioritas kebutuhan baru, konsumen cenderung akan meminta perbaikan demi kualitas. Serta persaingan yang dinamis akan membuat konsumen dimanjakan, cepat jenuh dan menuntut hal yang baru.

Seiring dengan pendapat Sriwarno (2014) mengenai desain dan faktor manusia, bahwa manusia akan selalu mengalami kejenuhan terhadap suatu produk. Kejenuhan akan suatu produk dapat dijawab dengan sebuah desain inovatif melalui eksperimen material baru. Menurutnya, produk desain yang menarik dan fun dapat menciptakan fenomena baru sebagai jawaban dari kejenuhan akan desain yang ada.

Maka berdasarkan pemaparan diatas, peneliti mengkaji lebih lanjut peluang pengembangan material baru, yaitu keramik Bone China untuk menciptakan fenomena baru sebagai produk aksesoris fashion berbasis teknologi digital sebagai peluang membuat desain yang fun sekaligus sebagai peluang solusi dari kejenuhan terhadap desain yang telah ada di era digital saat ini. 


\section{Metode dan Pembahasan}

\subsection{Metodologi Penelitian}

Metode yang digunakan dalam penelitian ini adalah metode kualitatif dengan interpetasi dari data yang dipaparkan. Penelitian ini menggunakan metode pengumpulan data studi pustaka yang bertujuan untuk menggambarkan dan memaparkan serta melihat peluang pengembangan dari objek yang dikaji

Studi pustaka yang dilakukan meliputi definisi dan fenomena yang terjadi terkait dengan keramik Bone China sebagai objek utama serta berkaitan dengan aksesoris fashion dan era digital untuk melihat peluang pengembangan dari objek utama.

\subsection{Subjek Penelitian}

Subjek dalam penelitian ini adalah keramik Bone China. Keramik berasal dari kata keramos, yang berarti tanah liat yang dibakar. Dalam bahas Sanskrit, keramik adalah proses pembakaran yang berasal dari kata keram. Istilah keramik juga sering dihubungkan dengan kata pottery dalam bahasa Inggris, dan tembikar atau gerabah dalam bahasa Indonesia. Dalam filosofi Yunani Kuno, keramik dianggap sebagai kombinasi yang sempurna dari empat elemen: bumi, angin, air dan api. Keramik terbuat dari tanah, dibentuk menggunakan air, dikeringkan menggunakan angin, dan dikokohkan dengan api. Dalam era modern, sains dan seni memberikan kontribusi terhadap definisi keramik. Keramik adalah material yang memiliki mikrostruktur yang terdiri dari fasa kristalin dengan atau tanpa fasa gelas dan terbuat dari material anorganik bukan logam melalui proses pembakaran. Formula kimia keramik dapat ditulis sebagai $\mathrm{Al}_{2} \mathrm{O}_{3} 2 \mathrm{SiO}_{2} 2 \mathrm{H}_{2} \mathrm{O}$.

Keramik dapat digolongkan kedalam banyak golongan dan sub golongan. Berdasarkan komposisi utamanya, Bone China digolongkan kedalam body keramik triaksial plus karena memiliki bahan tambahan mineral triaksial, yaitu abu tulang, yang memberikan sifat tembus bayang. Disamping itu, berdasarkan kepadatan, warna body, dan sifat fisiknya, Bone China termasuk kedalam golongan keramik berbody keras, sub golongan dari Chinaware. Chinawares memiliki warna body putih. Suhu pembakarannya berkisar antara $1200-1250^{\circ} \mathrm{C}$ dan memiliki sifat tembus bayang sesuai ketebalan bodynya. Penyerapan airnya berkisar 0-2\%.

Karakter unik dari keramik Bone China menjadi potensi yang masih dapat dikembangkan selain penggunaannya sebagai dinnerware, armature lampu dan perhiasan seperti cincin, anting dan gelang. 


\section{Lusiana}

Potensi Keramik Bone China sebagai Aksesoris Fashion Era Digital

\subsection{Keramik}

Berdasarkan sifatnya yang berwarna putih dan tembus bayang, Bone China digunakan sebagai tableware, khususnya untuk dinnerware. Warnanya yang lembut dan sifat tembus bayangnya, ia dapat membuat makanan diatasnya lebih menonjol dan menarik. Abu tulang juga memberikan sifat tahan api, sehingga aman untuk makanan yang panas. Disamping itu, keramik tembus bayang ini juga digunakan sebagai armature lampu karena dapat menghasilkan efek cahaya yang fluorescent. Efek fluorescent sangat baik digunakan utuk di restoran, café, and hotel karena membangun suasana yang hangat, romantis dan intim. [Lusiana, 2009; Ismi, 2012]. (lihat gambar 1 dan 2.)

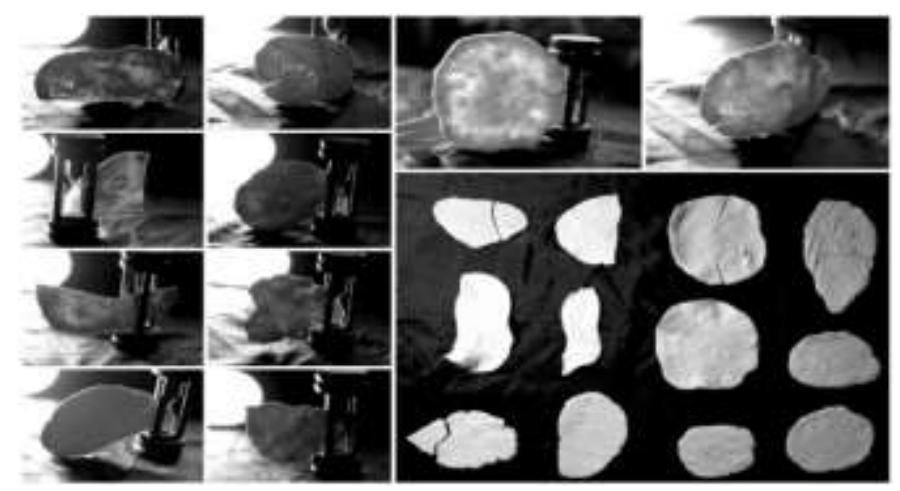

Gambar 1: Beberapa percobaan keramik Bone China dengan sifat tembus bayang Sumber: koleksi pribadi (2014)

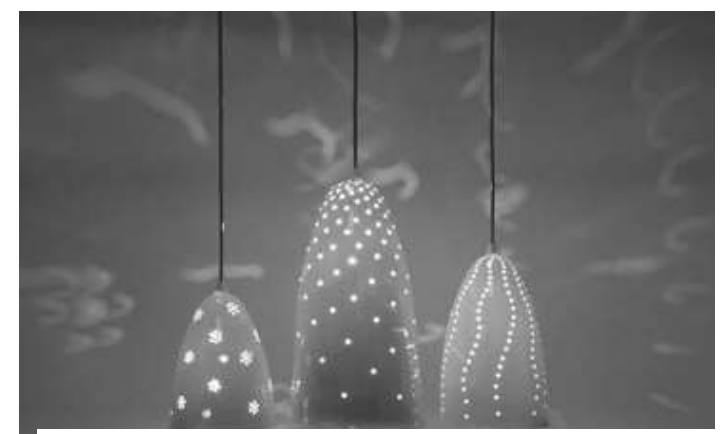

Gambar 2: contoh armature lampu keramik Bone China Sumber: www.google.com/bone_china. (24 Juli 2014 10:45 AM)

Sejauh ini, keramik Bone China telah digunakan sebagai perhiasan oleh beberapa artisan keramik di dunia. Seperti yang dilakukan oleh Rikke Jacobsen yang dikenal telah membuat perhiasan menggunakan bahan Bone China dalam konsep gaya Scandinavian spirit. Semua koleksi perhiasannya merefleksikan konsep yang elegan, bersahaja dan indah (lihat gambar 2.) 


\section{Lusiana}

Potensi Keramik Bone China sebagai Aksesoris Fashion Era Digital

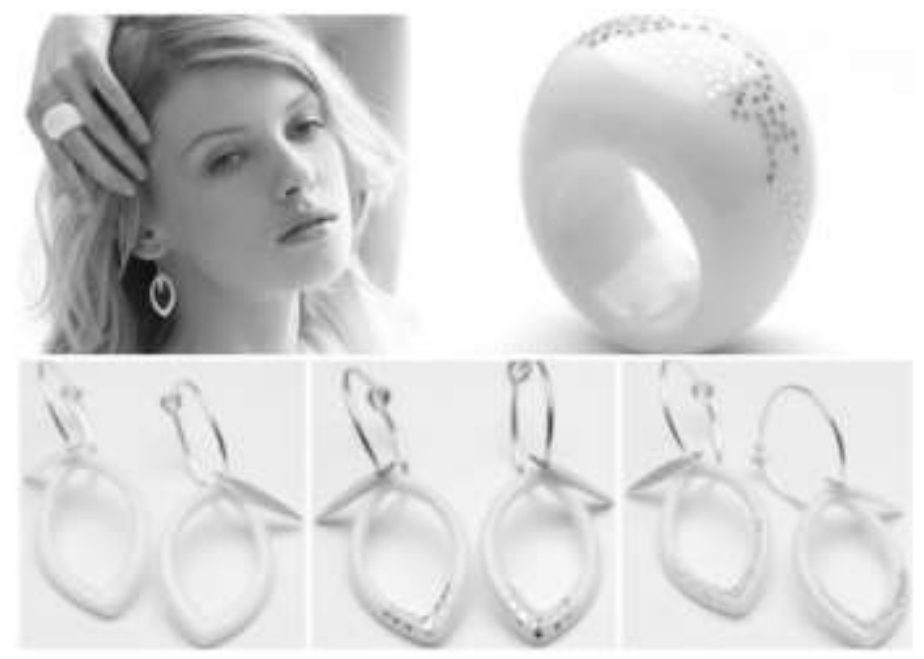

Gambar 2: Perhiasan Bone China karya Rikke Jacobsen Sumber: www.wonmark.com (24 Juli 2014)

Perhiasan tersebut memiliki sifat yang hampir ringkih padahal sebenarnya lebih kuat dari jenis bahan keramik lainnya. Hal tersebut membuat keramik Bone China memiliki karakter unik dan anggun sebagai perhiasan.

Para pengrajin dan studio keramik di Bandung pun, beberapa menggunakan Bone China sebagai material membuat perhiasan, seperti yang dilakukan oleh KAR studio dengan alasan bahwa Bone China berbobot lebih ringan dibandingkan jenis keramik lain, sehingga perhiasan dapat dipakai lebih nyaman. (lihat gambar 3)

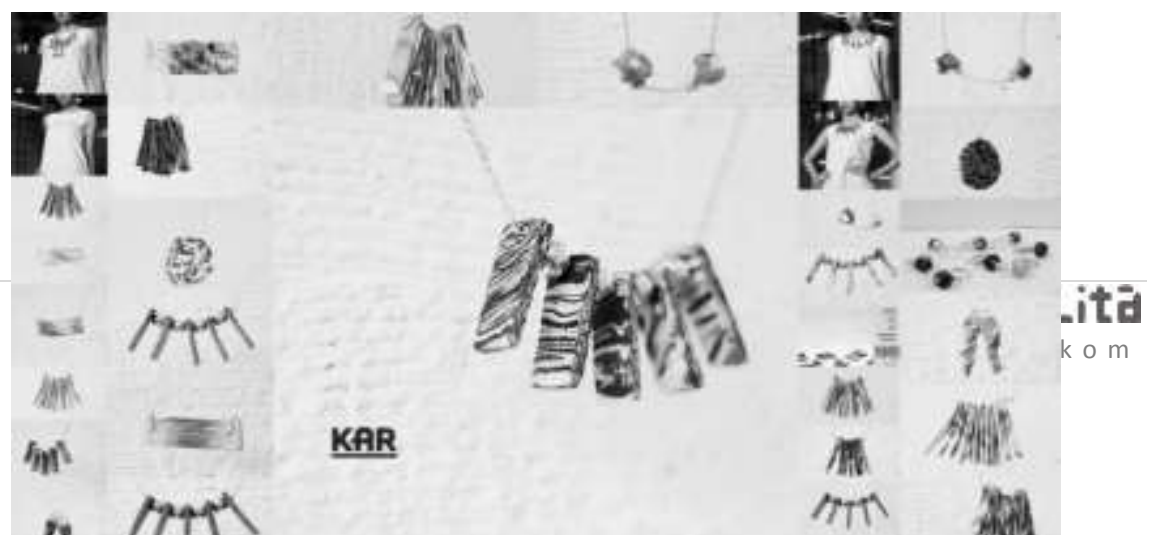


Gambar 3: Kalung karya studio KAR yang terbuat dari keramik Bone China Sumber: www.kar.com (24 Juli 2014)

Dengan keunikaan dan keanggunannya, Bone China dapat dikembangkan sebagai material perhiasan dan aksesoris kaum perempuan. Sifat tembus bayangnya yang biasa dipakai sebagai armature lampu, ada peluang untuk dikombinasikan dengan teknologi digital. Dengan demikian terdapat peluang untuk menciptakan fenomena produk baru yang seiring dengan perkembangan teknologi digital saat ini.

\section{$2.4 \quad$ Aksesoris Fashion}

Fashion, sebagaimana manusia, selalu berubah dan menjadi bagian dari budaya popular. Fashion menjadi simbol kebaruan yang menunjukan eksistensi akan identitas manusia dalam semua aspek kehidupannya [Solomon, 2004]. Fashion menunjukan gaya hidup sebuah masyarakat sekaligus melakukan fungsinya sebagai makhluk yang berbudaya. fashion menjadi media untuk mengaktualisasikan dan mengekspresikan diri.

Fashion memainkan peranan penting dalam masyarakat modern, sebagaimana hasil analisa perilaku konsumen oleh Solomon dan Rabolt [2008]. Teori dandanan mengatakan bahwa atribut fashion meliputi ornamen, dekorasi, dan ekspresi estetis, yang merepresentasikan status dan identitas penggunanya. Dandanan direpresentasikan oleh penampilan luar seperti pakaian, aksesoris, gaya rambut, dan sebagainya.

Pemilihan gaya fashion sangat tergantung pada keserasiannya. Untuk mencapai keserasian dalam fashion, sangat dibutuhkan suatu elemen pendukung yang biasa sebut sebagai aksesoris. Aksesoris fashion haruslah sesuai dengan pakaian yang digunakan serta momen pemakaiannya. Menurut Harriet Posner [2011] dalam bukunya, Marketing Fashion, produk yang dapat dikategorikan sebagai aksesoris fashion adalah sepatu, tas, kacamata, sarung tangan, syal, dompet, topi, dasi, perhiasan, ikat pinggang, bros dan lain-lain. 
Tampilan produk fashion dan aksesorissnya sangat dipengaruhi oleh keinginan dan kebutuhan pemakainya. Seperti halnya fashion, kebutuhan akan aksesoris dipengaruhi oleh beberapa aspek yang berkaitan dalam teori perilaku konsumen [Solomon, 2008] yaitu:

(a) Kebutuhan untuk berkelompok. Kebutuhan ini merupakan kebutuhan untuk menjadi bagian dari sebuah kelompok orang. Kebutuhan ini sejalan dengan produk dan jasa yang dikonsumsi oleh sekelompok orang tertentu untuk merasakan kebersamaan diantara mereka.

(b) Kebutuhan akan kekuatan. Produk dan jasa sangat mampu untuk menciptakan rasa menguasai terhadap sesuatu. Sebagai contoh, seorang pemimpin akan terlihat lebih pantas dan lebih berkuasa ketika menggunakan pakaian jas formal dibandingkan dengan memakai jeans.

(c) Kebutuhan untuk menjadi unik. Kebutuhan ini untuk menunjukan identitas individu. Fashion merupakan alat untuk menunjukan keunikan seorang individu, yang pada dasarnya setiap individu akan selalu ingin terlihat berbeda dari satu dan yang lainnya.

Kebutuhan akan aksesoris fashion dapat kita temukan dari hasil sensus yang dilakukan oleh www.accessoriesmagazine.com pada tahun 2011 mengenai prediksi pangsa pasar aksesoris fashion ditahun 2012 berdasarkan klasifikasinya. (lihat gambar 5) 
Gambar 5: Prediksi pangsa pasar aksesoris fashion di tahun 2012 berdasarkan klasifikasinya

Sumber: www.accessoriesmagazine.com (10 Mei 2014)

Hasil survei tersebut menunjukan bahwa adanya indikasi perhiasan sebagai pangsa pasar terbesar dibandingkan dengan jenis aksesoris fashion lainnya, dengan jumlah $36.65 \%$. hal ini menunjukan bahwa adanya peluang besar untuk mengembangkan produk perhiasan baik dalam perkembangan desain maupun penggunaan materialnya. Inovasi sangat terbuka lebar sejalan dengan perkembangan teknologi di era digital saat ini.

Hingga saat ini, hampir semua perhiasan seperti kalung, gelang, anting, bros, dan cincin selalu menggunakan material emas atau perak. Padahal jika dilihat dari sejarahnya, perhiasan tidak hanya menggunakan material emas dan perak, tetapi juga kerang-kerangan, keramik, akar, serat, kulit, tulang dan kayu.

\subsection{Era Digital}

Era digital adalah sebuah jaman yang mengalami perubahan teknologi dari teknologi berbasis mekanik dan elektronik menjadi berbasis digital. Perubahan ini telah terjadi sejak tahun 1980 dan masih berlangsung hingga saat ini, bahkan semakin berkembang pesat. Perubahan ini mempengaruhi hampir semua aspek kehiduan manusia seperti halnya teknologi informasi, sosial, politik, desain, agrikultur, kesehatan, pendidikan dan bidang lainnya.

Era digital ditandai dengan ditemukannya komputer. Semua sistem computer berbasis teknologi digital. Kata digital itu sendiri berasal dari bahasa Yunani, digitus, yang memiliki makna jari, yang kita gunakan untuk menghitung dari nol hingga sepuluh. Angka sepuluh terdiri dari dua angka, 1 dan 0 . Kemudian, digital berarti penggambaran sebuah kondisi angka yang terdiri dari digit 0 dan 1 , atau off dan on (angka biner)

Seiring dengan perkembangan komputer, era digital juga ditandai dengan lahirnya internet dan World Wide Web (www). Saat ini, hampir setiap negara di dunia dapat 
terkoneksi dengan internet dengan akses informasi yang bebas. Perkembangan era digital berkembang sangat pesat setelah ditemukannya dan bertambahnya industri gadget seperti handphone, smartphone dan tablet. Seiring dengan itu, muncul juga jejaring sosial, yang saat ini memiliki pangsa pasar terbesar yang membentuk budaya era digital.

Era digital telah mempengaruhi dan merubah pola hidup masyarakat saat ini. Masyarakat di era digital memiliki akses yang lebih cepat terhadap informasi dimanapun dan kapanpun. Mereka menjadi ingin selalu terkoneksi dengan internet sepanjang waktu, kapan pun dan melalui alat apapun.

Masyarakat era digital memiliki akses mudah terhadap informasi yang relevan dan bermanfaat bagi mereka karena dapat meningkatkan produktivitas. Masyarakat era digital juga dapat mengatur dan menyusun jadwal kerja mereka dengan bantuan perangkat digital. Mereka memiliki kebutuhan akan kebersamaan yang tinggi dan membuat mereka sangat bergantung dengan teknologi untuk tetap berhubungan dengan keluarga dan teman mereka dimanapun mereka berada. Mereka selalu meng-update informasi secara real time, termasuk fashion. Dalam memilih produk fashion, mereka memilih untuk mengikuti gaya yang dipakai oleh komunitasnya dan dalam waktu yang sama, mereka juga ingin terlihat unik, untuk menunjukan indentitasnya sebagai seorang individu.

Dalam era digital, penampilan adalah segalanya. "kamu bergaya, maka kamu ada!", merupakan kalimat yang menunjukan kegandrungan masyarakat modern terhadap gaya. Itulah alasan mayoritas industri gaya hidup adalah industri gaya, baik dalam bidang jasa maupun produk. [Ibrahim, 2003].

Produk di era digital memiliki karakteristik berteknologi canggih, tepat, terukur, mengutamakan kecepatan, modern, dan berkonsep futuristik. Future atau masa depan adalah penggambaran hasil pemikiran manusia mengenai kehidupan yang akan datang. Futuristik dalam arsitektur memiliki persamaan kata dengan teknologi mutakhir, cepat, aerodinamis, dan mengekspos konstruksi. Futuristik digambarkan dengan warna-warna yang monokrom, silver, hitam, putih, penggunaan material logam, kaca, dan warna yang mengkilat. Warna lain juga dapat menunjukkan kesan yang futuristic jika warna tersebut bersifat metalik, seperti warna merah metalik, biru metalik dan seterusnya.

Dalam fashion, gaya futuristik dianggap sebagai sesuatu yang lebih dari sekedar modern. Yakni sebuah desain yang dapat menggambarkan kekuatan di masa depan karena busana akan selalu berubah dan berkembang dari waktu ke waktu. Dapat disimpulkan bahwa fashion yang bergaya futuristik adalah yang berorientasi pada masa depan atau yang gayanya selalu mengikuti perkembangan jamannya. 


\subsection{Aksesoris Fashion berbahan Dasar Keramik Bone China dan Berteknologi Digital}

Sebagaimana wanita dan fashion sebagai dua hal yang tak dapat dipisahkan, begitupun dengan pakaian dan aksesoris. Seperti yang telah dipaparkan oleh www.accessoriesmagazine.com, hasil survey aksesoris di tahun 2011 tersebut mengindikasikan bahwa perhiasan memiliki pangsa pasar terbesar dibandingkan jenis aksesoris lainnya. Hal ini menunjukan besarnya peluang pengembangan produk perhiasan baik desain maupun materialnya.

Berdasarkan hasil observasi, keramik Bone China dapat mencapai kesan yang elegan, sehingga sangat potensial untuk sebuah desain yang modern futuristik, terutama ketika dikombinasikan dengan teknologi digital. Sebagaimana slogan yang dikenal di era modern yang serba digital ini, bahwa penampilan adalah segalanya, yaitu "kamu bergaya, maka kamu ada!" juga seiring dengan karakteristik fashion yang selalu mengikuti perkembangan jamannya.

Sebagaimana fashion yang berkembang mengikuti perembangan jamannya, begitu pun aksesoris fashion yang merupakan bagian tak dapat terpisahkan darinya. Aksesoris fashion menjadi kebutuhan penting bagi wanita yang hidup di era digital. Sebagaimana teori perilaku konsumen Solomon dan Rabolt, mereka memiliki kebutuhan akan keunikan untuk menunjukkan identitas mereka sebagai seorang individu. Hal ini menunjukkan peluang besar untuk mengembangkan material keramik Bone China sebagai material utama aksesoris fashion, sehingga karakter yang dimiliki oleh keramik ini dapat dioptimalkan, termasuk sifatnya yang tembus bayang membuka peluang untuk dikombinasikan dengan teknologi digital sehingga desain aksesoris dapat seiring dengan perkembangan jaman saat ini.

Pengembangan material Bone China ini seiring dengan pendapat Sriwarno (2014) mengenai desain dan faktor manusia, bahwa manusia akan selalu mengalami kejenuhan terhadap suatu produk. Kejenuhan akan suatu produk dapat dijawab dengan sebuah desain inovatif melalui eksperimen material baru. Menurutnya, desain produk yang menarik dan fun dapat menciptakan fenomena baru sebagai jawaban dari kejenuhan akan desain yang ada.

Desain aksesoris yang menarik dan fun untuk wanita modern era digital, dapat dicapai dengan eksplorasi material baru seperti keramik Bone China ini, dan dipadankan dengan memainkan desain-desain yang geometris atau komposisi bentuk geometris dan penggunaan warna yang monokrom, silver, hitam, putih atau perpaduan warna metalik dan penggabungan dengan konsep digital sehingga lebih sesuai dengan jamannya. 


\section{Kesimpulan}

Penelitian ini dapat memberikan inspirasi untuk menciptakan aksesoris keramik untuk masyarakat era digital Indonesia terutama bagi kaum perempuan yang lebih cenderung tak bisa lepas dengan fashion. Untuk masyarakat umum dan penelitian selanjutnya, penelitian ini menjadi wawasan tambahan dan ide awal untuk meciptakan produk keramik yang dapat digabungkan dengan teknologi digital sehingga karakteristik dari keramik dapat teroptimalisasikan. Ide ini pun dapat menajadi ide solusi untuk permasalahan akibat perkembangan jaman yang akan selalu memunculkan prioritas kebutuhan baru serta akibat persaingan pasar yang dinamis, menimbulkan kejenuhan dan menuntut hal yang baru.

Contoh desain untuk mengoptimalisasikan keramik Bone China sehingga dapat menciptakan produk aksesoris fashion yang sesuai dengan perkembangan era digital, menjadi solusi kejenuhan akan produk yg ada dan menjadi produk inovasi, adalah :

1. Gelang atau kalung keramik yang dapat berfungsi sebagai perhiasan sekaligus sebagai jam digital. Semua material body gelang/liontin kalung terbuat dari keramik Bone China termasuk layar ntuk jam digitalnya. Mungkin dapat digunakan sensor panas untuk memunculkan fungsi jam digitalnya diatas permukaan gelang/liontin keramik tersebut.

2. Gelang/kalung/bross keramik yang dapat berubah warna dan dapat dikontrol melalui applikasi dari smartphone. Warna aksesoris keramik tersebut dapat disesuaikan dengan pakaian atau atribut lainnya yang sedang dipakai sehingga dapat lebih serasi. Mungkin dapat menggunakan lampu LED, mikro controller dan teknologi Bluetooth untuk perangkat dan pengaturan warnanya.

\section{Referensi}

Accessories Staff. 2012. Accessories Census 2011, Accessories Magazine, www.accessoriesmagazine.com, (march 21, 2012), (http://www.accessoriesmagazine.com/40508/accessories-census-2011\#), diakses tanggal: 10 Mei 2014, pukul 08:44 WIB.

Hamer, Frank. 1975. The Potter's Dictionary of Materials and Technique. London: Pitman Publishing

Harriet, Posner. 2011. Marketing Fashion. London: Laurence King Publishing Ltd.

Ismi, Kania Diedra., Joedawinata, Dr. Ahadiat. 2012. Aplikasi Motif dan Tekstur Embroidery pada Perangkat Pencahayaan dengan Material Bone China. Jurnal Tingkat Sarjana Bidang Senirupa \& Desain. Bandung: FSRD, ITB 
ITS. 2014. Desain Interior kafe Axis dalam Nuansa Futuristik. http://digilib.its.ac.id/public/ITS-Undergraduate-6977-3405100002-Bab1.pdf, diakses tanggal: 13 Juli 2014, pukul 13.22 WIB.

Lusiana. 2009. Ekplorasi Kerang-Kerangan untuk Lampu Dekorasi Restauran Seafood. Bachelor Final Project Art and Design Faculty. Bandung: FSRD ITB

Melvis. 2012. Fine New Bone China Jewelry by Rikke Jacobsen, www.wonmark.com, (Dec 19, 2012). (http://wonmark.com/fine-new-bone-china-jewelry-by-rikkejacobsen/) diakses tanggal: 24 Juli 2014, pukul 13:45 WIB.

Riyanto, Dra. Arifah A. 2003. Teori Busana. Bandung: Penerbit Yapemdo.

Sindo. 2012. Mengungkap Evolusi Gelang, www.okezone.com, (Januari 20, 2012). (http://lifestyle.okezone.com/read/2012/01/20/29/560701/mengungkapevolusi-gelang) diakses tanggal: 13 juli 2014, pukul 13:30 WIB.

Solomon, Michael R. \& Rabolt, Nancy J. 2004. Consumer Behavior in Fashion, New Jersey: Prentice Hall

Storey, John., 2006. Cultural Studies dan kajian Budaya Pop, pengantar komprehensif teori dan metode, Yogyakarta: Jalasutra

Suparta, Adnan Ross. 2006. Reka Bahan Keramik Jilid I. Bandung: Penerbit ITB

Yovine. 2012. Geometry for Futuristic Fashion. (http://geometryarchitecture.wordpress.com access date: 12 July 2014, 11.30 PM), diakses tanggal: 13 juli 2014, 13:45 WIB. 